\title{
Financial Liberalization and Stock Markets Integration for Asean-5 Countries
}

\author{
Sew-Ming Phuan \\ OCBC Bank (M) Bhd, 352-356 Ground Floor \\ Jalan Tuanku Abdul Rahman, 50100 Kuala Lumpur, Malaysia \\ E-mail: phuansming@ocbc.com \\ Kian-Ping, Lim \\ Monash University, Melbourne, Australia \\ Universiti Malaysia Sabah, Labuan F.T, Malaysia \\ E-mail: kianpinglim@yahoo.com \\ Ai-Yee Ooi \\ School of International Business and Finance Labuan \\ Universiti Malaysia Sabah, 11700 Jalan Sg. Pagar, Labuan F.T, Malaysia \\ E-mail: ooiaiyee@yahoo.co.uk
}

\begin{abstract}
This paper examines the relationship of financial liberalization and stock markets integration among ASEAN-5 (Note 1) stock markets: Indonesia, Malaysia, the Philippines, Singapore and Thailand. Three sample periods are covered based on the progress of financial liberalization. By using Johansen and Juselius multivariate cointegration procedures, Granger-causality tests and variances decomposition analysis, the results indicate no long-run relationship during Singapore stock market liberalization in the first period. However, long-run relationship established between ASEAN-5 stock markets in the second period when Thailand, Malaysia and Indonesia have liberalized their stock markets and the third period following the Philippines liberalization. The long run integration relationships and the short-run causality relationships among ASEAN-5 markets have both increased after the financial liberalization. Thailand, Malaysia, Indonesia and the Philippines markets have received increased influences from other stock markets in the progress of financial liberalization whereas Singapore remains unaffected by the others. Stock markets that liberalize earlier will have greater influence on other stock markets.
\end{abstract}

Keywords: Financial liberalization, Stock markets integration, ASEAN-5 stock markets, Portfolio diversification

\section{Introduction}

The study of market integration holds important implications for the theory of financial economics in the degree to which markets are integrated determines the benefits from diversification of investment portfolios. Recent years have seen considerable attention devoted to the analysis of linkages among stock markets in different countries. After the stock market crash in October 1987, there was a considerable interest in investigations of the linkages between stock markets. A decade later, the financial crisis of 1997 in Asian markets has renewed this interest. This issue is an important concern for investors because greater integration among stock markets implies that reducing the opportunities for international diversification. Interest in this topic has also been enhanced by the liberalization of financial markets, progressive relaxation of controls on international capital movements and the increasing importance of cross-border equity flows. (Note 1)

Equity market liberalization could have a favorable impact on the country economy in many aspects. Several empirical studies have shown that liberalization has had a positive effect on developing economies via the decreased cost of equity, increased returns, increased private physical investment and the growth of economics. (Note 2) Stock market liberalization, if effective, will lead to important changes in both the financial and real sectors as the countries stock 
markets become integrated into world stock markets. The existence and absence of integration and interdependencies involves several important issues, including the benefits to portfolio diversification and development of the policy frameworks. Traditionally investors have considered only developed markets in their international diversification strategy. These markets have been in operation for a long time and most international performance benchmarks included only developed markets. However, investor interest in emerging markets appears to have increased significantly over the last few years. As noted by Kawakatsu and Morey (1999), the result of the financial liberalization had been quite dramatic as in 1985, the flow of foreign portfolio investment into emerging markets was only US\$138 million. However, by 1993, the Dow had increased to a remarkable US\$45 billion. The study of Shawky et al. (1997) also mentioned that the net foreign capital flow to emerging equity markets in 1993 was around $\$ 37$ billion. The foreign inflow of capital also helped spark a boom in emerging markets stock prices, as studied by Henry (2000a), the real dollar price of all emerging market equity increased by more than 300\% from December 1984 to December 1994.

The ASEAN countries that from the most to the least developed, have been working diligently to enhance the efficiency, strength and depth of their financial systems. One of those significant developments occurred in these ASEAN economies is the implementations of deregulation and liberalization of financial market in the region. Development of the financial sector has been a salient policy goal for most ASEAN member since the mid-1980s. In the latter half of 1980s and early years of 1990s, most of the governments of ASEAN have gradually liberalized their stock markets. (Note 3) Stock market liberalization is a decision by a country's government to allow foreigners to purchase shares in that country's stock market. It gives foreign investors the opportunity to invest in domestic equity securities and domestic investors the right to transact in foreign equity securities.

The five ASEAN stock markets namely Indonesia, Malaysia, the Philippines, Singapore and Thailand are the countries originally included in the Association of South East Asian Nations (ASEAN) when the Bangkok Declaration was signed on 8 August 1967. These ASEAN countries have been trying to diversify their heavy reliance on the banking sector in favor of other financial intermediation vehicles including stock and fixed-income markets. Importantly, it limits the way in which a financial system can price risk efficiently. Hence, while one would always expect the banking sector to assume a key financial intermediary role in the ASEAN countries, and fostering its health should be a perpetual priority, the development of alternative markets could be extremely important for the long-run growth and development of the financial sector, as well as the entire economy. Therefore, greater emphasis by ASEAN on the development of stock and bond markets is not only appropriate but also essential.

The spectacle of price collapses around the world during the October 1987 stock market crash provided an early warning to the country about the risk elements embedded in those integrated financial markets. In the 1997, East Asian financial and currency crisis further demonstrated how powerless a group of integrated economies could become in the midst of financial market meltdowns and the degree of market integration among some of these countries had become sufficiently high to facilitate the worst contagion of financial crisis. Rather than looking through a global perspective, this study will just focus on the five major ASEAN stock markets.

There also exists little empirical evidence concerning the factor that causes short and long-term market linkages among ASEAN countries. This is an important omission since notions of stock markets integration have obvious implications for comovements between stock markets. Many international studies concerned with market linkages are relatively commonplace. Example the studies of Masih and Masih (1997a,b, 1999, 2001a,b, 2002), Bekaert, Harvey and Lumsdaine (2001), Leong and Felmingham (2001), Phylaktis and Ravazzolo (2002, 2005), Drew and Chong (2002) and Bekaert, Harvey and $\mathrm{Ng}$ (2003) are subject to increasing attention, but few studies have adopted an exclusively ASEAN perspective. No study to date has examined stock market linkages across the broad spectrum of ASEAN-5 member stock markets that take into account of the factor of financial liberalization. An investigation of the factors that influence the dynamic linkages and relationship among the stock markets are needed to provide a better grasp of the functioning of the stock markets to the investor and policy makers. This paper attempts to examine the factor of financial liberalization that becomes one of the factors causing the stock markets integration.

For most emerging markets, liberalization is an essential policy tool that attracts much needed foreign capital for investment purposes. Financial literature has presented a strong emphasis on the integration on stock markets with the interest increased considerably following the abolition of foreign exchange controls, the introduction of innovative financial products, such as Country Funds and American Depository Receipts, which have created more opportunities for global international investments. Thus, this implies that financial liberalization has contributed to the stock markets integration. However, studies from Phylaktis and Ravazzolo (2005) examined the effect of stock market liberalization on financial linkages among seven Asian capital markets (Japan, Hong Kong, South Korea, Malaysia, Singapore, Taiwan and Thailand) and the U.S. over two sub-periods: the 1980-1989 pre-liberalization period and the 1990- 1998 post-liberalization period. The results show that all the stock markets are not linked together for both the 80s and the 90s periods and that the U.S plays a small role while Japan's role is more significant. Similar results were found for the open markets of Hong Kong and Malaysia for the 80s. This evidence suggests that the relaxation of foreign exchange 
restrictions is not sufficient to attract international investors' attention and strengthen international market interrelations. Related findings from Bekaert and Harvey (2000), they point out liberalization may not be enough to induce foreign investors to actually invest in the country.

This study aims to investigate whether the process of financial liberalization has contributed to the stock market integration in the context of ASEAN-5: Indonesia, Malaysia, the Philippines, Singapore and Thailand, whereby these countries have a different economic and financial structure and political background. If these ASEAN-5 stock markets are independent then investors can diversify their portfolio in these different stock markets. On the other hand, the authorities in the region need not worry about any contagious effects if one market experiences any turmoil. As highlighted by Shawky et al. (1997) portfolio diversification is always a reasonable method of reducing the risk of an investment portfolio without negatively affecting its return expectations.

\section{Data and Methodology}

\subsection{Data}

This paper examines the relationship between emerging stock markets in five ASEAN countries, namely Indonesia (Jakarta S.E. Composite), Malaysia (Kuala Lumpur Composite), the Philippines (S.E. Composite), Singapore (Straits Times Index) and Thailand (Bangkok S.E.T.). The daily closing values, denominated in home-country currencies and the data set is obtained from Kuala Lumpur Stock Exchange (KLSE). All the series are transformed into natural logarithm form. The full sample period covering the period of 2/01/1986 to 30/06/1997 is further divided into three sub-periods. First sub-period covers from 2/01/1986 to 31/08/1987. In this period only Singapore has liberalized it stock market and there is a need to investigate whether Singapore was the earliest country that liberalized it stock market and can it lead to the ASEAN-5 stock market being cointegrated. The second sub-period starts from 1/09/1987 to 30/06/1991, this period include three countries, which is Thailand, Malaysia and Indonesia that have liberalized their stock markets. It needs to investigate whether more countries liberalizing their stock markets can leads to the ASEAN-5 stock markets being more cointegrated. The last sub-period covers from 1/07/1991 to 30/06/1997, when the Philippines liberalized it stock market in ASEAN-5. In this period, all ASEAN-5 stock markets are liberalized and employed the data before the 1997 Asian crisis to avoid the critical period. It's more important within the scope of this paper to investigate the stock market reactions on whether financial liberalization can contribute to the stock market being more integrated compared with the first and second periods.

\subsection{Methodology}

This study has employed the unit root test to determine whether data series are stationary. The Johansen and Juselius (1990) multivariate cointegration technique that uses maximum likelihood procedures is employed to determine the number of cointegration vectors among a vector of time series. Cointegration test is test to determine whether a linear combination of the variables under consideration is stationary and optimal lag has to be selected by using Akaida Information Criterion (AIC). Given that the variables are integrated to the order one, a causal long-term relationship might be present among these non-stationary variables. In order to examine the short-run relationships, Granger (1969) causality tests are specified. Essentially tests of the prediction ability of time series models, an index causes another index in the Granger sense if past values of the first index explain the second, but past values of the second index do not explain the first. Finally an unrestricted vector autoregressive (VAR) variance decomposition test will be conducted. The objective is to analyze the degree to which a change in one country's stock price exerts an influence on a change in other countries' stock price series. The variance decomposition test will show the proportion of the movements in the stock index that is due to its own shocks versus those originating from other markets.

\section{Empirical Results}

Augmented Dicker Fuller (ADF) tests of the null hypothesis of nonstationarity are performed on each of the ASEAN-5 stock prices indices in level and first-differenced forms for the three sub-periods. Analysis of the levels series indicates non-stationarity for all markets at 0.01 levels. However, all of the ADF test statistics are significant at the 0.01 levels in first differenced form, indicating stationarity and showed that the indices with differences sub sample periods are integrated at the same order of one or I (1).

Johansen and Juselius' procedure (1990) multiple cointegration vectors are used to examine whether the ASEAN-5 stock price indices are cointegrated and also to obtain the cointegration rank. The tests provide different finding on the cointegrating relationships over each sub-periods. The trace test statistics indicated that the order of cointegration is 1 during first and second periods whereas the order of integration of two happens in the last period. In terms of linkages of long-run nature, the results suggest that the stock market indices are bonded together by long-run relationships in the second and third period but not in the first period. Therefore, financial liberalization contributed to the stock markets integration is significant established.

The Granger causality test result depicted in Figure 3.1. In the first period, the causal relationships are running from Thailand to Indonesia market, Singapore to Malaysia and Thailand to the Philippines. Thailand seems as a leader 
whereby it affected two countries, Indonesia and Philippines. No feedback is found among ASEAN-5 and they're just a few causality relationships only. The result offer some evidence that the earliest country liberalized their stock markets countries (Singapore) and the country that start to liberalizing their stock market (Thailand) tend to lead the market that haven't liberalized their stock market yet. During the second period, Singapore is found causal the Malaysia and Thailand markets and affected by Malaysia and the Philippines. There is two-way causal relationship found in Singapore and Malaysia markets. On the other hand, the Philippines are leading the Singapore and Malaysia markets. (Note 4) Thailand does not causal any other countries and it effected by Singapore only. Surprisingly, other markets do not affect the Indonesia and the Philippines market in this period. Indonesia does not being led by other countries in the second period. The disappearance of its causal links with other markets could be it is the last country that liberalized it stock market in the second period. In the third period witnesses some changes to the causality relationship. The causation from Philippines to Singapore and Malaysia not longer exist. The Philippines does not affected any others market, however it affected by Singapore market. In this period, Indonesia market is affects by the Malaysia market and Thailand market. There are two-way causal relationships between Indonesia and Thailand markets. Malaysia market and the Philippines market are found causal by Singapore market only. However, Singapore is not causal by other markets and it became a leader to Malaysia, Thailand and Philippines markets.

For both three periods of the financial liberalization progress, it can be observed that the linkages have increased after all ASEAN-5 countries liberalized their stock markets. It is also found that the earliest country that liberalized their stock markets (Singapore) has an increased affected on those stock markets that were not liberalized yet (i.e. Malaysia, Thailand, the Philippines). This implies an increase in integration among ASEAN-5 stocks markets after the financial liberalization on stock markets. Thus, provide a significance of this paper is whereby the integration of the ASEAN-5 will limit the benefits of portfolio diversification by investors in this region. (See Figure 1)

Insert Figure 1 Here

\section{Variance Decomposition Analysis}

The variance decomposition for 5, 10,15,20, 25 and 30 days forecasts error variances of the ASEAN-5 member stock markets for the three sub-periods are reported in Table 3.1. The entries in the table are the percentages of return forecast error variance of a market that can be explained by random innovations of its own market as well as those of the other markets.

For Singapore market, the average $94.406 \%$ is explained by its own forecast error variances, whereas average $0.080 \%$ variance is explained by Thailand market, $0.052 \%$ (Malaysia), $0.091 \%$ (Indonesia) and $5.370 \%$ (Philippines) in the first period. The average variance explained by other countries falls from $5.594 \%$ to $4.182 \%$, mainly due to the decreased influence in the Philippines market. The Singapore market in the third period, averaging of $99.530 \%$ is explained by its own forecast error variances. In the context of Thailand market, Singapore explained an average $10.118 \%$ of the variance to Thailand market in the first period and increased to average $42.703 \%$ the second period. Singapore is the most influence in the Thailand market and this consistent with the causation relationship. However, the total external influences from Singapore decreased to $17.337 \%$ in the third period. Malaysia, Indonesia and the Philippines face the decreased influences on the Thailand market. Malaysia market explains only average $40.185 \%$ of its own forecast error variances, whereas an average $55.595 \%$ of variance is explained by the Singapore market in the first period. In the second period, Singapore explains a major portion of its variance with average of $74.866 \%$ to Malaysia market. However, the external influences from Singapore grew weakly in the third period, but still explained a highly forecast of error variance about $47.214 \%$ to Malaysia market. For Indonesia market, Thailand explained an average of $4.888 \%$ of the variance in Indonesia market in the first period. In the second period, the external influence decreased to $1.061 \%$ thus this is similar with the causality result which Indonesia does not have any linkages with the other four markets. The average of $98.939 \%$ was explained by it own forecast error variances. However, in the third period, the average $21.945 \%$ out of $27.399 \%$ of its forecast variances are explained by the Singapore market mainly due to the Singapore effect having grown stronger from average $0.462 \%$ to $21.945 \%$. In the Philippines market, Thailand market explains a major portion of its variance to the Philippines market, which is $8.250 \%$ in the first period. In the second period, the total influence to the Philippines market increased from $13.318 \%$ to $16.731 \%$ mainly due to increased influences by Singapore market. Surprisingly, the external influences have increased from $16.731 \%$ to $25.014 \%$ after the financial liberalization, mainly due to the influence of Singapore.

The results show that the variation in Singapore is greatly explanative by itself for the three periods while Thailand, Malaysia, Indonesia and the Philippines were explained by the other stock markets. Thailand, Malaysia and the Philippines received increased influences from external factors and Singapore, Indonesia are received decrease influence in the second period. For the third period, the evidence of increasing influence from external factors is from the stock market of Indonesia and the Philippines. On the other hand, Singapore and Thailand and Malaysia faced a decrease after all ASEAN-5 stock market had liberalized. But, it still shows that the Malaysia market is still highly explained by the Singapore market with the average of $47.214 \%$. Generally, Singapore market showed a continue 
decrease the external factors that explained it market after the liberalization. Meanwhile, only the Philippines stock market is showing a continued increase the external factor, followed by the progress of financial liberalization in the three periods. Malaysia market is the most 'endogenous' market, which highly explained by Singapore market for the three periods. All the results give evidence that the integration of ASEAN-5 stock markets grow stronger after the financial liberalization in stock markets. It is found that those countries that liberalized their stock market later (Indonesia and the Philippines) are greatly receiving increasing influences from those earlier liberalized markets (Singapore and Thailand and Malaysia.). (See Table 1)

Insert Table 1 Here

\section{Conclusion}

The findings show that after all the ASEAN-5 financial liberalization, Singapore is not causal by other markets and it became a leader that mainly affected to Malaysia, Thailand and Philippines markets. The variation in Singapore has greatly explanative by itself for the three periods while Thailand, Malaysia, Indonesia and the Philippines was explained by other stock markets. These results are supported by Roca et al. (1998) that Singapore market is the dominant in influencing the other four stock markets.

It is interesting to note that Thailand, Malaysia and the Philippines receive increased influences from external factors. The major external factors come from the stock markets of Indonesia and the Philippines. Malaysia market is the most 'endogenous' market, which highly explained by Singapore market for the three periods. More interestingly, those countries that liberalized their stock market later (Indonesia and the Philippines) are greatly receiving increasing influences from those earlier liberalized markets (Singapore and Thailand and Malaysia). The results are in line with the study by Yang and Siregar (2001), suggest clearly that the financial liberalizations have enhanced interaction and integration between the stock markets in the Asia-Pacific region.

In summary, ASEAN-5 stock markets become more integrated after the financial liberalization in the long run perspective. The ASEAN-5 stock markets share a common trend that implies the markets move together and driven by common shocks, which have a permanent effect, providing limited long-term gains to international diversification. From the view of investor, market integration will reduce the scope for diversification possibilities. The benefits of any diversification are limited within the region. Therefore, investors with long run horizons may not benefit from an investment made across the countries in this ASEAN region.

Further research is suggested to take others factor into consideration such as the ASEAN economic cooperation and the advanced of Information technology to compare the main influences that bring to the linkages of ASEAN stock markets. The financial liberalization leads to the increasing in ASEAN-5 stock market integration raises the fundamental questions: Does the financial liberalization bring the advantages to the ASEAN-5 stock markets? This is important for the investor to well allocate their investment in to a good portfolio diversification. This paper shows the evidence of financial liberalization will cause the stock market becomes more integrated in the long run. Thus, this will limit the participation of the foreign investors whereby they will looking ASEAN-5 countries in a group that the stock markets are not be the choice for the portfolio diversification. Therefore, the future research is warranted to shed more light on whether the ASEAN-5 market stock prices have become more efficient after the financial liberalization.

\section{References}

Bekaert, G. \& Harvey, C. R. (1995). Time Carrying World Integration. Journal of Finance. 50: 403-444.

Bekaert, G. \& Harvey, C. R., (2000). Foreign Speculators and Emerging Equity Markets. Journal of Finance. 55: 29-77.

Bekaert, G., Harvey, C. R. \& Lumsdaine, R. L. (2002). Dating the integration of world equity markets. Journal of Financial Economics. 65: 203-247.

Bekaert, G., Harvey, C. R. \& Lumsdaine, R. L. (1999). The Dynamics of emerging market equity flows. Journal of International Money and Finance. 21: 295-350.

Bekaert, G., Harvey, C. R. \& Lundblad, C. T. (2001). Emerging equity markets and economic development. Journal of Development Economics. 66: 465-504.

Bekaert, G., Harvey, C. R. \& Lundblad, C. T. (2004). Does financial liberalization spur growth? Journal of Financial Economics. 77: 3-55.

Bekaert, G., Harvey, C. R. \& Lundblad, C. T. (2002). Growth Volatility and Equity Market Liberalization. Unpublished working paper. National Bureau of Economic Research, Cambridge, MA.

Bekaert, G., Harvey, C. R. \& Ng, A. (2003). Market Integration and Contagion. Working Paper 9510. National Bureau of Economic Research, Cambridge, MA.

Chari, A. \& Henry, P. B. (2001). Stock Market Liberalizations and the Repricing of Systematic Risk. Working Paper 101. Center for Research on Economic Development and Policy Reform. 
Das, M. \& Mohapatra, S. (2003). Income inequality: the aftermath of stock market liberalization in emerging markets Journal of Empirical Finance. 10: 217-248.

Drew, M. \& Chong, L. (2002). Stock Market Interdependence: Evidence from Australia. Discussion papers in Economics, Finance and International Competitiveness. No. 106.

Engle, R. F. \& Granger, C. W. J. (1987). Cointegration and error correction: representation, estimation and testing. Econometrica. 55: 251-276.

Eun, C. S. \& Shim, S. (1989). International transmission of stock market movements. Journal of Finance and Quantitive Analysis.24: 241-256.

Granger, C. W. J. (1969). Investigating causal relationships by econometric models and cross spectral models. Economerica. 37: 424-438.

Henry, P. B. (2000b). Stock Market Liberalization, Economic Reform, and Emerging Market Equity Prices. Journal of Finance. 55: 529-563.

Henry, P. B., (2000a). Do stock market liberalizations cause investment booms? Journal of Financial Economics. 58: 301-334.

Johansen, S. \& Juselius, K. (1990). Maximum Likelihood Estimation and Inference on Cointegration with Applications to Money Demand. Oxford Bulletin of Economics and Statistics. 52: 169-210.

Kaminsky, G. L. \& Schmukler, S. L. (2002). Short-Run Pain, Long-Run Gain: The Effects of Financial Liberalization. Working Paper. National Bureau of Economic Research, Cambridge, MA.

Kawakatsu, H. \& Morey, M.R. (1999). Financial liberalization and stock market efficiency: an empirical examination of nine emerging market countries. Journal of Multinational Financial Management. 9: 353-371.

Kim, E. \& Singal, V. (2000). Stock Market openings: experience of emerging economies. Journal of Business. 73:25-66.

Leong. S. C. \& Felmingham. B. (2003). The interdependence of share markets in the developed economies of East Asia. Pacific-Basin Finance Journal. 11: 219-237.

Masih, A. M. M. \& Masih, R. (1997a). A comparative analysis of the propagation of stock market fluctuations in alternative models of dynamic causal linkages, Applied Financial Economics. 7: 59-74.

Masih, A. M. M. \& Masih, R. (1997b). Dynamic linkages and the propagation mechanism driving major international stock markets: an analysis of the pre- and post-crash eras. The Quarterly Review of Economics and Finance, 37(4): 859-885.

Masih, A. M. M. \& Masih, R. (2001a). Dynamic modeling of stock market interdependencies: an empirical investigation of Australia and the Asian NICs. Review of Pacific Basin Financial Markets and Policies. 4(2): 235-264.

Masih, A. M. M. \& Masih, R. (1999). Are Asian stock market fluctuations due mainly to intra-regional contagion effects? Evidence based on Asian emerging stock markets. Pacific-Basin Finance Journal. 7: 251-282.

Masih, R. \& Masih, A. M. M. (2001b). Long and short term dynamic causal transmission amongst international stock markets. Journal of International Money and Finance. 20: 563-87.

Masih, R. \& Masih, A. M. M. (2002). Propagative causal price transmission among international stock markets: evidence from the pre- and post globalization period. Global Finance Journal. 13: 63-91.

Neaime, S. (2002). Liberalization and Financial Integration on MENA Stock Markets. Paper presented at the Economic Research Forum Ninth Annual Conference, Al-Sharjah, UAE, October 26-28, 2002.

Phylaktis, K. \& Ravazzolo, F. (2002). Measuring financial and economic integration with equity prices in emerging markets. Journal of International Money and Finance. 21: 879-903.

Phylaktis, K. \& Ravazzolo, F. (2005). Stock Market Linkages in Emerging Markets: Implications for International Portfolio Diversification. Journal of International Financial Markets, Institutions and Money. 15: 2, 91-106.

Roca, E. D., Selvanathan, A. \& Shepherd, W. F. (1998). Are the Asean equity markets interdependent? ASEAN Economic Bulletin. 15: 109-120.

Shawky, H. A., Kuenzel, R. \& Mikhail, A. D. (1997). International portfolio diversification: a synthesis and an update. Journal of International Financial Markets, Institutions \& Money. 7: 303-327.

Sims, C. A. 1980. Macroeconomics and reality. Econometrica. 48:1-48.

Yang, T. \& Siregar, R. (2001). An Empirical Examination of the Stock Market Returns in Selected Asia-Pacific Economies in the Pre- and Post-Financial Reform Period. Economics and Finance.11: 1-64. 


\section{Notes}

Note 1. See Bekaert and Harvey (2000), Henry (2000a,b) Bekaert, Harvey and Lumsdaine (2002), Bekaert, Harvey and Lundblad (2001, 2002, 2004), Chari and Henry (2001), Kamisky and Schmukler (2002), Neaime (2002), Das and Mohapatra (2003).

Note 2. See Bekaert and Harvey (2000), Bekaert, Harvey and Lumsdaine (2002), Bekaert, Harvey and Lundblad (2001, 2002, 2004), Henry (2000a,b), Kim and Singal (2000).

Note 3. See example from Bekaert \& Harvey (2000) for more details on financial liberalization progress.

Note 4. The Singapore markets lead by the Philippines may be due the high investment by Singapore in the Philippines.

Table 1. Variance Decomposition Analysis Results

Table 1 a. SINGAPORE

Percentage of $\mathrm{k}$ days ahead forecast error variance of Singapore stock indices accounted by the innovation of Thailand, Malaysia, Indonesia and the Philippines.

First period: 1986.01-1987.08

\begin{tabular}{|c|c|c|c|c|c|}
\hline $\mathrm{k}$ & SINGAPORE & THAILAND & MALAYSIA & INDONESIA & PHILIPPINES \\
\hline 1 & 100.000 & 0.000 & 0.000 & 0.000 & 0.000 \\
\hline 5 & 98.703 & 0.005 & 0.062 & 0.054 & 1.178 \\
\hline 10 & 96.792 & 0.012 & 0.048 & 0.087 & 3.060 \\
\hline 15 & 94.627 & 0.031 & 0.034 & 0.109 & 5.198 \\
\hline 20 & 92.388 & 0.075 & 0.038 & 0.124 & 7.375 \\
\hline 25 & 90.201 & 0.155 & 0.066 & 0.132 & 9.446 \\
\hline 30 & 88.132 & 0.280 & 0.118 & 0.134 & 11.336 \\
\hline Average & 94.406 & 0.080 & 0.052 & 0.091 & 5.370 \\
\hline \multicolumn{6}{|c|}{ Second period: $1987.09-1991.06$} \\
\hline $\mathrm{k}$ & SINGAPORE & THAILAND & MALAYSIA & INDONESIA & PHILIPPINES \\
\hline 1 & 100.000 & 0.000 & 0.000 & 0.000 & 0.000 \\
\hline 5 & 97.366 & 0.087 & 0.444 & 0.022 & 2.081 \\
\hline 10 & 95.257 & 0.161 & 0.241 & 0.210 & 4.132 \\
\hline 15 & 94.683 & 0.333 & 0.167 & 0.494 & 4.324 \\
\hline 20 & 94.555 & 0.527 & 0.136 & 0.675 & 4.107 \\
\hline 25 & 94.492 & 0.770 & 0.127 & 0.839 & 3.772 \\
\hline 30 & 94.376 & 1.055 & 0.130 & 0.993 & 3.446 \\
\hline Average & 95.818 & 0.419 & 0.178 & 0.462 & 3.123 \\
\hline \multicolumn{6}{|c|}{ Third period: $1991.07-1997.06$} \\
\hline $\mathrm{k}$ & SINGAPORE & THAILAND & MALAYSIA & INDONESIA & PHILIPPINES \\
\hline 1 & 100.000 & 0.000 & 0.000 & 0.000 & 0.000 \\
\hline 5 & 99.557 & 0.043 & 0.024 & 0.373 & 0.003 \\
\hline 10 & 99.469 & 0.030 & 0.017 & 0.481 & 0.003 \\
\hline 15 & 99.439 & 0.025 & 0.015 & 0.518 & 0.003 \\
\hline 20 & 99.424 & 0.023 & 0.014 & 0.536 & 0.003 \\
\hline 25 & 99.415 & 0.022 & 0.013 & 0.548 & 0.002 \\
\hline 30 & 99.408 & 0.021 & 0.013 & 0.556 & 0.002 \\
\hline Average & 99.530 & 0.023 & 0.014 & 0.430 & 0.002 \\
\hline
\end{tabular}


Table $1 \mathrm{~b}$. THAILAND

Percentage of $\mathrm{k}$ days ahead forecast error variance of Thailand stock indices accounted by the innovation of Singapore, Malaysia, Indonesia and the Philippines.

First period: 1986.01-1987.08

\begin{tabular}{llllll}
\hline $\mathrm{k}$ & SINGAPORE & THAILAND & MALAYSIA & INDONESIA & PHILIPPINES \\
\hline 1 & 0.255 & 99.745 & 0.000 & 0.000 & 0.000 \\
5 & 1.520 & 97.455 & 0.007 & 0.958 & 0.061 \\
10 & 4.658 & 93.964 & 0.004 & 1.336 & 0.038 \\
15 & 8.878 & 89.466 & 0.006 & 1.617 & 0.034 \\
20 & 13.648 & 84.413 & 0.011 & 1.869 & 0.060 \\
25 & 18.555 & 79.189 & 0.013 & 2.101 & 0.141 \\
30 & 23.311 & 74.063 & 0.013 & 2.311 & 0.301 \\
Average & 10.118 & 88.328 & 0.008 & 1.456 & 0.091 \\
\hline
\end{tabular}

\begin{tabular}{llllll}
\hline \multicolumn{2}{l}{ Second period: $1987.09-1991.06$} & & & & \\
\hline $\mathrm{k}$ & SINGAPORE & THAILAND & MALAYSIA & INDONESIA & PHILIPPINES \\
\hline 1 & 18.408 & 81.592 & 0.000 & 0.000 & 0.000 \\
5 & 37.507 & 61.702 & 0.012 & 0.577 & 0.201 \\
10 & 46.241 & 50.932 & 0.629 & 0.729 & 1.469 \\
15 & 48.332 & 48.003 & 0.891 & 0.491 & 2.284 \\
20 & 49.201 & 46.859 & 0.958 & 0.386 & 2.596 \\
25 & 49.555 & 46.372 & 1.001 & 0.327 & 2.745 \\
30 & 49.676 & 46.198 & 1.026 & 0.287 & 2.813 \\
Average & 42.703 & 54.523 & 0.645 & 0.400 & 1.730 \\
\hline
\end{tabular}

Third period: 1991.07-1997.06

\begin{tabular}{llllll}
\hline $\mathrm{k}$ & SINGAPORE & THAILAND & MALAYSIA & INDONESIA & PHILIPPINES \\
\hline 1 & 9.756 & 90.244 & 0.000 & 0.000 & 0.000 \\
5 & 17.494 & 82.099 & 0.181 & 0.042 & 0.184 \\
10 & 18.630 & 80.865 & 0.175 & 0.025 & 0.304 \\
15 & 18.873 & 80.573 & 0.159 & 0.024 & 0.371 \\
20 & 18.910 & 80.496 & 0.142 & 0.029 & 0.423 \\
25 & 18.877 & 80.493 & 0.128 & 0.035 & 0.467 \\
30 & 18.818 & 80.519 & 0.116 & 0.042 & 0.506 \\
Average & 17.337 & 82.184 & 0.129 & 0.028 & 0.322 \\
\hline
\end{tabular}


Table 1 c. MALAYSIA

Percentage of $\mathrm{k}$ days ahead forecast error variance of Malaysia stock indices accounted by the innovation of Singapore, Thailand, Indonesia and the Philippines.

First period: 1986.01-1987.08

\begin{tabular}{|c|c|c|c|c|c|}
\hline$\underline{\mathrm{k}}$ & SINGAPORE & THAILAND & MALAYSIA & INDONESIA & PHILIPPINES \\
\hline 1 & 33.485 & 0.582 & 65.932 & 0.000 & 0.000 \\
\hline 5 & 51.095 & 0.122 & 48.321 & 0.353 & 0.109 \\
\hline 10 & 56.369 & 0.097 & 42.016 & 0.949 & 0.569 \\
\hline 15 & 59.458 & 0.094 & 37.500 & 1.679 & 1.270 \\
\hline 20 & 61.590 & 0.082 & 33.720 & 2.487 & 2.121 \\
\hline 25 & 63.080 & 0.071 & 30.489 & 3.317 & 3.043 \\
\hline 30 & 64.087 & 0.081 & 27.729 & 4.128 & 3.975 \\
\hline Average & 55.595 & 0.161 & 40.815 & 1.845 & 1.584 \\
\hline \multicolumn{6}{|c|}{ Second period: $1987.09-1991.06$} \\
\hline$\underline{\mathrm{k}}$ & SINGAPORE & THAILAND & MALAYSIA & INDONESIA & PHILIPPINES \\
\hline 1 & 66.987 & 0.437 & 32.576 & 0.000 & 0.000 \\
\hline 5 & 72.819 & 0.259 & 25.415 & 0.023 & 1.484 \\
\hline 10 & 77.798 & 0.441 & 18.569 & 0.048 & 3.144 \\
\hline 15 & 77.962 & 0.760 & 17.730 & 0.151 & 3.397 \\
\hline 20 & 77.313 & 1.065 & 18.218 & 0.216 & 3.188 \\
\hline 25 & 76.247 & 1.413 & 19.193 & 0.275 & 2.872 \\
\hline 30 & 74.936 & 1.792 & 20.372 & 0.329 & 2.571 \\
\hline Average & 74.866 & 0.881 & 21.725 & 0.149 & 2.379 \\
\hline \multicolumn{6}{|c|}{ Third period: 1991.07-1997.06 } \\
\hline$\underline{\mathrm{k}}$ & SINGAPORE & THAILAND & MALAYSIA & INDONESIA & PHILIPPINES \\
\hline 1 & 38.927 & 1.654 & 59.419 & 0.000 & 0.000 \\
\hline 5 & 46.723 & 2.059 & 51.116 & 0.055 & 0.047 \\
\hline 10 & 48.450 & 2.259 & 49.055 & 0.034 & 0.202 \\
\hline 15 & 48.973 & 2.464 & 48.050 & 0.069 & 0.443 \\
\hline 20 & 49.155 & 2.661 & 47.276 & 0.164 & 0.745 \\
\hline 25 & 49.173 & 2.847 & 46.591 & 0.303 & 1.086 \\
\hline 30 & 49.099 & 3.021 & 45.956 & 0.474 & 1.450 \\
\hline Average & 47.214 & 2.423 & 49.638 & 0.157 & 0.567 \\
\hline
\end{tabular}


Table $1 \mathrm{~d}$. INDONESIA

Percentage of $k$ days ahead forecast error variance of Indonesia stock indices accounted by the innovation of Singapore, Thailand, Malaysia and the Philippines.

First period: $1986.01-1987.08$

\begin{tabular}{llllll}
\hline $\mathrm{k}$ & SINGAPORE & THAILAND & MALAYSIA & INDONESIA & PHILIPPINES \\
\hline 1 & 0.138 & 0.061 & 0.015 & 99.785 & 0.000 \\
5 & 0.575 & 1.845 & 0.016 & 96.727 & 0.836 \\
10 & 0.551 & 3.292 & 0.117 & 94.736 & 1.305 \\
15 & 0.502 & 4.818 & 0.300 & 92.667 & 1.713 \\
20 & 0.475 & 6.425 & 0.513 & 90.491 & 2.096 \\
25 & 0.477 & 8.067 & 0.722 & 88.285 & 2.448 \\
30 & 0.512 & 9.706 & 0.913 & 86.112 & 2.758 \\
Average & 0.462 & 4.888 & 0.371 & 92.686 & 1.594 \\
\hline
\end{tabular}

\begin{tabular}{llllll}
\hline \multicolumn{2}{l}{ Second period: $1987.09-1991.06$} & & & & \\
\hline $\mathrm{k}$ & SINGAPORE & THAILAND & MALAYSIA & INDONESIA & PHILIPPINES \\
\hline 1 & 0.016 & 0.109 & 0.047 & 99.829 & 0.000 \\
5 & 0.329 & 0.315 & 0.055 & 99.249 & 0.052 \\
10 & 0.520 & 0.374 & 0.118 & 98.944 & 0.044 \\
15 & 0.666 & 0.335 & 0.130 & 98.803 & 0.066 \\
20 & 0.772 & 0.318 & 0.137 & 98.692 & 0.081 \\
25 & 0.878 & 0.302 & 0.140 & 98.582 & 0.099 \\
30 & 0.978 & 0.288 & 0.140 & 98.475 & 0.118 \\
Average & 0.594 & 0.292 & 0.110 & 98.939 & 0.066 \\
\hline Third period: $1991.07-1997.06$ & & & & \\
\hline $\mathrm{k}$ & SINGAPORE & THAILAND & MALAYSIA & INDONESIA & PHILIPPINES \\
\hline 1 & 7.616 & 0.390 & 0.923 & 91.072 & 0.000 \\
5 & 18.073 & 1.372 & 2.940 & 77.464 & 0.151 \\
10 & 22.037 & 1.337 & 3.748 & 72.754 & 0.124 \\
15 & 24.224 & 1.283 & 4.483 & 69.928 & 0.082 \\
20 & 25.897 & 1.229 & 5.177 & 67.616 & 0.081 \\
25 & 27.288 & 1.179 & 5.828 & 65.591 & 0.113 \\
30 & 28.482 & 1.134 & 6.433 & 63.781 & 0.171 \\
Average & 21.945 & 1.132 & 4.219 & 72.601 & 0.103 \\
\hline
\end{tabular}


Table 1 e. THE PHILIPPINES

Percentage of $\mathrm{k}$ days ahead forecast error variance of the Philippines stock indices accounted by the innovation of Singapore, Thailand, Malaysia and Indonesia.

\begin{tabular}{llllll}
\multicolumn{5}{l}{ First period: $1986.01-1987.08$} \\
$\mathrm{k}$ & SINGAPORE & THAILAND & MALAYSIA & INDONESIA & PHILIPPINES \\
\hline 1 & 0.078 & 0.581 & 0.062 & 0.022 & 99.258 \\
5 & 0.729 & 3.697 & 0.117 & 0.006 & 95.451 \\
10 & 2.002 & 6.243 & 0.094 & 0.004 & 91.657 \\
15 & 3.824 & 8.676 & 0.209 & 0.003 & 87.287 \\
20 & 6.121 & 10.953 & 0.395 & 0.004 & 82.526 \\
25 & 8.771 & 12.962 & 0.594 & 0.008 & 77.665 \\
30 & 11.646 & 14.639 & 0.772 & 0.013 & 72.931 \\
Average & 4.739 & 8.250 & 0.320 & 0.009 & 86.682 \\
\hline Second period: $1987.09-1991.06$ & & & & \\
\hline $\mathrm{k}$ & SINGAPORE & THAILAND & MALAYSIA & INDONESIA & PHILIPPINES \\
\hline 1 & 7.552 & 0.502 & 0.049 & 0.069 & 91.827 \\
5 & 12.274 & 0.482 & 0.418 & 0.443 & 86.383 \\
10 & 16.705 & 0.458 & 0.286 & 0.402 & 82.148 \\
15 & 18.160 & 0.633 & 0.210 & 0.592 & 80.405 \\
20 & 18.185 & 0.745 & 0.176 & 0.707 & 80.186 \\
25 & 17.592 & 0.843 & 0.161 & 0.781 & 80.624 \\
30 & 16.779 & 0.930 & 0.154 & 0.831 & 81.307 \\
Average & 15.321 & 0.656 & 0.208 & 0.546 & 83.269 \\
\hline Third period: $1991.07-1997.06$ & & & & \\
\hline $\mathrm{k}$ & SINGAPORE & THAILAND & MALAYSIA & INDONESIA & PHILIPPINES \\
\hline 1 & 4.780 & 0.939 & 0.315 & 1.360 & 92.605 \\
5 & 13.410 & 2.120 & 1.620 & 1.747 & 81.104 \\
10 & 17.124 & 2.224 & 2.700 & 1.310 & 76.643 \\
15 & 19.860 & 2.178 & 3.816 & 0.944 & 73.202 \\
20 & 22.209 & 2.101 & 4.950 & 0.713 & 70.027 \\
25 & 24.275 & 2.017 & 6.065 & 0.595 & 67.049 \\
30 & 26.100 & 1.933 & 7.133 & 0.562 & 64.271 \\
Average & 18.251 & 1.930 & 3.800 & 1.033 & 74.986 \\
\hline & & & & &
\end{tabular}


Panel A: First Period- 1986.01-1987.08

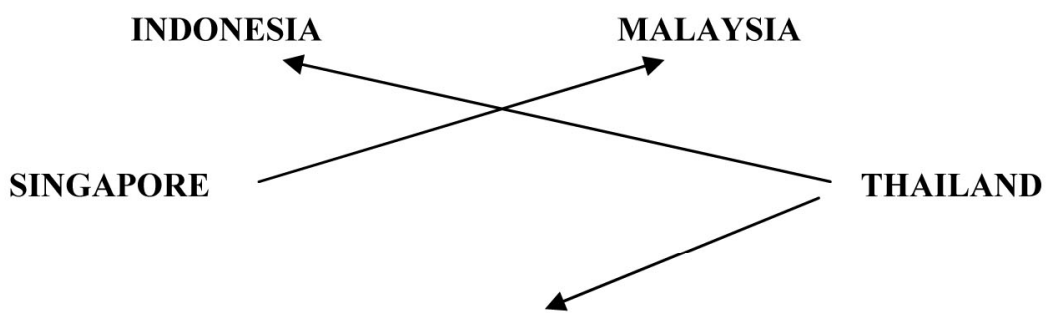

THE PHILIPPINES

Panel B: Second Period- 1987.09-1991.06

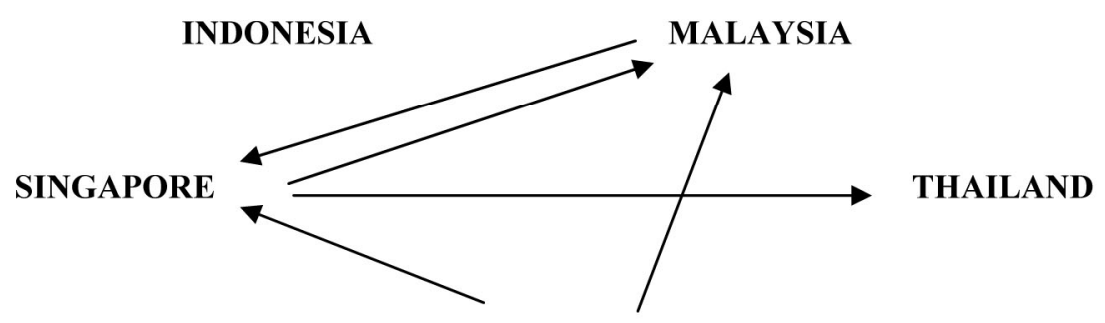

THE PHILIPPINES

Panel C: Third Period- 1991.07-1997.06

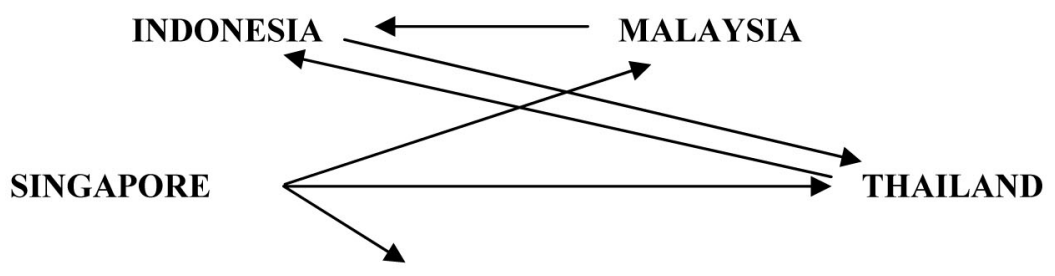

THE PHILIPPINES

Denote: " $\longrightarrow$ ": Indicates the 'causal' relationships exist. (Significant at 5\% level).

$\mathrm{X} \rightarrow \mathrm{Y}$ indicates that changes in $\mathrm{X}$ contain leading information for changes in $\mathrm{Y}$.

(i.e. changes in $\mathrm{X}$ granger cause changes in $\mathrm{Y}$ or changes in $\mathrm{Y}$ lags changes in $\mathrm{X}$ ).

$\mathrm{X} \longleftarrow \mathrm{Y}$ implies the reverse.

Figure 1. The summary results of Granger causality tests 